\title{
India's Urban Challenges and Smart Cities: A Contemporary Study
}

\section{MihirBholey, Ph.D}

Senior Faculty, Interdisciplinary Design Studies and Coordinator PG Science and Liberal Arts, National Institute of Design, Gandhinagar, Gujarat, INDIA.

c) Scholedge International Journal of Business Policy \& Governance (2394-3351), Vol.03, Issue 03 (2016) pg 17-38. Published by: Scholedge R\&D Center [http://www.thescholedge.org/journals/] [Email: sijbpg@scholedge.org]

\begin{abstract}
After coming to power in 2014 Prime Minister Narendra Modi's government announced the ambitious programme of building 100 smart cities in India. The idea behind is to rejuvenate the ailing urban system, improve urban infrastructure, quality of life and achieve sustainable and inclusive development besides other things. Tremendous demographic pressure, inadequate infrastructure and resources to cater to the population which runs in billions, unplanned growth of the peri-urban sprawls characterize India's urban environment. Socio-economic imperatives are the key factors behind the rapid urbanization in India. Livelihood, security and prosperity are some prime movers. Ironically, cities, which on the one hand are considered the growth engines of economy, also attract poverty (socio-economically marginalized population) in large proportion. Consequently posh urban sprawls in Indian cities exist amidst impoverished habitats called slums where the poor inhabitants are condemned to live in sub-human condition. Reconciling growing affluence and abject poverty in cities is a difficult task too. In the backdrop of India's urban challenges this paper seeks to examine some critical issues associated with the development of smart cities to understand: Will smart cities serve India's aspiration or fulfill its urban needs? Can it address the contemporary and future needs of India's urbanization? How will it ensure the participation of the urban stakeholders? How will it ensure social inclusion and finally, whether India needs smart cities or smart urban solutions for sustainable development?
\end{abstract}

Keywords: smart city, urbanization, design, sustainability, inclusive development, demography 


\section{Introduction}

India is urbanizing at the rate of $2.47 \%$ (annual rate of change $2010-15$ est). Nearly $31.3 \%$ or 37.71 million of its total 1.21 billion population is now urban (Chandramouli, 2011). According to McKinsey Global (2010), by 2025 it will add 215 million to its cities which will raise the urban population to $38 \%$. Not only this, by 2025 Mumbai and Delhi, its two megacities will become number two and three in the world ranking with expected population of 26.4 and 22.5 million respectively. The rising population and its migration will put tremendous pressure on its megacities, 7395 towns and 1456 urban agglomeration (as per Govt. of India 2011 census) for improved infrastructure and better service delivery. Rising population, rapidly changing demography, rising resource and infrastructure deficit, slack urban governance and poor service delivery are some of the major urban challenges in India which reflect on basic urban amenities such as water, sanitation, sewage, road, transportation among other. Can the proposed smart cities solve these problems?

The present models of smart cities in the world viz. Songdo (South Korea), Masdar (UAE), PlanIT Valley (Portugal) and the rest have been designed as urban systems which are both technology and capital intensive. In neighboring China frantic urbanization has built host of 'ghost cities" with no or few takers. The question is looking at its socio-cultural-economic diversity can India succeed in solving its problems of urbanization by adopting these techno and capital intensive models? Barring few exceptions like Chandigarh and Gandhinagar, urbanization in India has been an organic growth of habitat. Cities in India have seldom evolved on an architect or urban planner's drawing board. The socio-economic diversity itself can make assimilation of technology- a pre-requisite for smart cities, a big challenge. So the concept requires a thorough investigation from multiple perspectives including that of the stakeholders. Although, offering a permanent solution for something as complex and evolving as urbanization is easier said than done. Nevertheless, the need of short and long term strategies for sustainable urbanization cannot be ruled out.By the mid of this century nearly seventy percent of the world population will become urban. During the same period urbanization in India is also envisaged to surpass all; even to China. It certainly needs sustainable urban solutions.

\section{Challenges of Urbanization}

Urbanization is a major challenge of the $21^{\text {st }}$ century. While it has somewhat stabilized in the developed nations of the west, countries like India, China, Nigeria are urbanizing at a much faster pace. As per World Urbanization Prospect 2014, Revision report India is projected to 
add 404 million urban dwellers, China 292 million and Nigeria 212 million between 2014-2050. This will add additional pressure to the existing urban centres and also create the demand for more efficient and socio-economically and environmentally sustainable cities. It's estimated that by 2050 the present rate of population growth and urbanization will add 2.5 billion people to the world's urban population of which nearly 90 per cent of the increase will happen in Asia and Africa. Even today globally there're more people living in urban areas as compared to the rural areas. World Urbanization Prospect 2014, Revision counted54 per cent of the world's population residing in urban areas in 2014. While in 1950, 30 per cent of the world's population was urban, it's likely to become 66 percent by 2050 according to this report. Urbanization in India will be the highest followed by China and Nigeria by 2050 as seen in Figure 1.

\section{Figure 1}

Contribution to the increase in urban population by country, 2014 to 2050

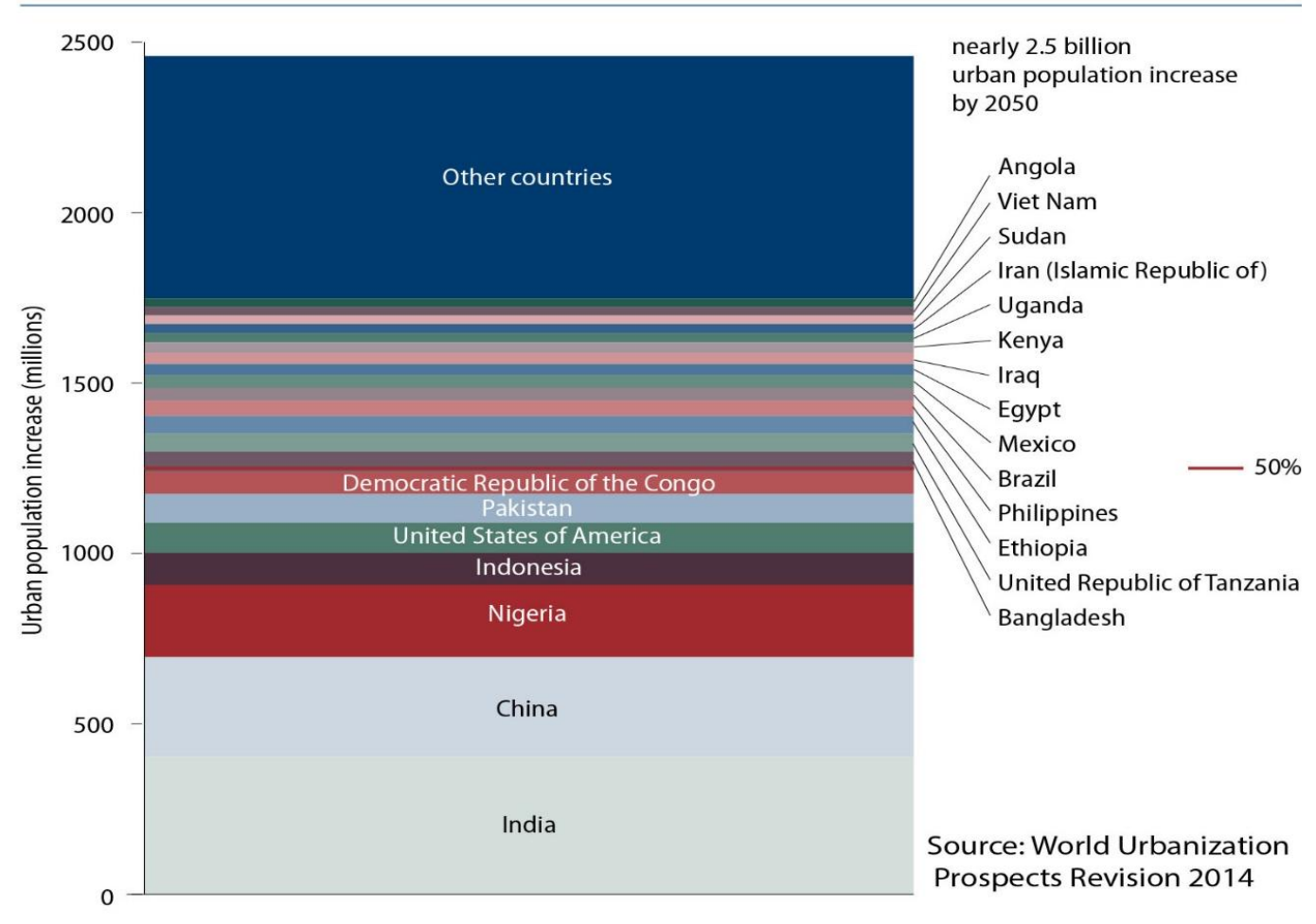

Note: The countries shown are projected to contribute 25 million or more to the global urban increment between 2014 and 2050. The category "Other countries" includes countries with urban increments of less than 25 million each.

Besides the three existing megacities - Delhi, Mumbai and Kolkata, by 2030 India will add up four more cities namely: Ahmedabad, Bangalore Chennai and Hyderabad in the list of its megacities taking the figure to seven. Megacities are characterized by their size and 
concentration of economic activity world over. However, they provide shelter to only one out of eight urban dwellers. There were only 10 cities having population in excess of 10 million inhabitants in 1990.These megacities were home to153 million people, which was less than 7 per cent of the total global urban population that time. Thirty-five years later in 2015 the number of megacities has substantially increased. It's 28 today with the cumulative population of 453 million;12 per cent of the world's urban population. Close to 31 percent of Indian population is now urban and growing. Figure 2 explains it.

Figure 2

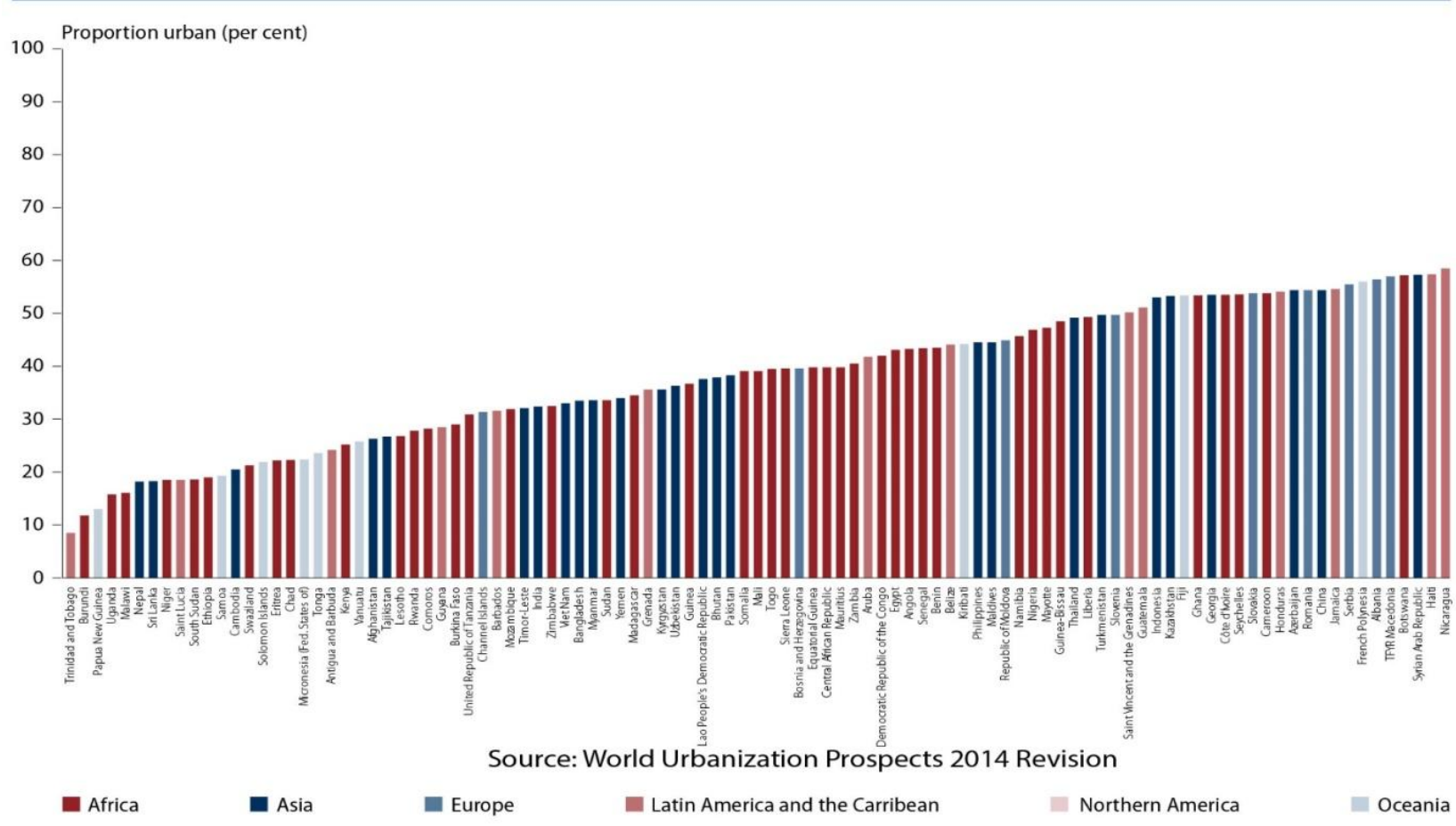

\section{India's Urbanization Challenges}

The growth of Indian cities has been organic. On the socio-economic and cultural spectrum they offer a wide variety in terms of range and kind. The heterogeneous nature adds to the complexity of urban planning as well. Ahluwalia et. al.(2014) observe the lack of planned development of Indian cities is the result of spatial planning not being central to the socioeconomic planning. They point out: 
"The consequence of this has been that the state of Indian cities, both with respect to building and maintenance of urban infrastructure as well as delivery of public services, is highly unsatisfactory, and is far short of what is required to sustain faster and more inclusive growth of the economy." (Ahluwaliaet. al. 2014: 2)

The question inevitably arises - where is the gap, whether at the policy or at implementation level? A democratic constitution that India has, nurtures the ideal of social inclusion in words and spirit. Good governance and satisfactory service delivery are some of the basic expectations of the people from the government. However, converting spirit into action is often better said than done. It's because as Paul (2014) observes democracy doesn't always function as per the script. Policies change but at their own pace and in many cases often fall short of the need of the hour and expectations. For better urban functioning change is required at levels of policies, institutions and governance simultaneously. Stakeholders' participation in terms of articulating the need is a must but also a rare opportunity whereas the $74^{\text {th }}$ Constitutional Amendment ensures more empowered local democracy. This is a major concern when it comes to the development of 100 smart cities. Although Prime Minister Modi in one of his statements has highlighted that: "For the first time in India, a challenge was being floated, in which the citizens of urban India could contribute in the formulation of development visions of their cities." (HT, June 25, 2015). Looking at the socio-culturaleconomic diversity of India and taking lesson from the past mistakes, the government seems keen to have the stakeholders on board when it comes to this new phase of urbanization through smart cities.

\section{Affordable Housing}

There's no doubt that Indian cities are growing in proportion and prosperity. However, social inclusion of the weaker sections remains a big challenge. The skewed relation between supply and demand of affordable urban housing is a major issue. As far as the government is concerned, semantics of the term 'affordable housing' is quite different for it. Sengupta (2012) points out: “For the most part 'affordable housing' has been loosely synonymous with low-income housing in all government documents.'In fact "affordable housing" is used in reference to different income ranges and the sizes of the unit. So to make it precise, the Taskforce on Promoting Affordable Housing (2012) under the Ministry of Housing and Urban Poverty Alleviation has defined the concept of 
affordable housing as:"individual dwelling units with a carpet area of not more than 60 sq.mt. and preferably within the price range of five times the annual income of the household." The investment in housing sector by the corporatized construction companies shows little interest towards the policy of social inclusion for obvious reasons of lower margin of profit. No doubt, scare supply of land and high cost of construction are other disincentives too. To fill up the gap in the housing and infrastructure sector the government of India under Jawaharlal Nehru Urban Renewal Mission (JNNURM) has adopted 63 cities which include 7 mega cities, 28 metro cities and 28 capital cities and towns. However, this intervention has also not been of much help. Consequently, the weaker sections either live in the ghettoized communities or in the sprawl of slums. Even under the Land Acquisition Act 2015, affordable housing has been given high priority, which even private builders also have to follow.

KPMG (2014) report on Indian Real Estate estimates that the affordable housing sector alone is expected to account for 85-90 percent of total residential development, which would mean construction of 40-45 million housing units by 2028. While countries like the UK clearly spelt out their inclusionary zoning by 1990, India made its National Urban Housing and Habitat Policy in 2007. The Unitary Development Plan (2002) of the UK earmarked 25 percent of its housing units to be affordable if it's provided on site and 33 percent in case it's provided off site. The Land Act 2007 of Spain makes it mandatory to have 30 percent of its new houses affordable. (Ahluwalia, Mohanty 2014). In 2007 India introduced its National Urban Housing and Habitat Policy which underscored the need of:

\footnotetext{
"Creating adequate housing stock both on rental and ownership basis with special emphasis on improving the affordability of the vulnerable and economically weaker sections through appropriate capital or interest subsidy"(NUHP 2007: 14)
}

Through its flagship programme JNNURM government has articulated its intent to include the poor population in urban planning and development. It also encourages the State Governments, Urban Local Bodies, Development Authorities to update their Master Plans and Zoning Plans from time to time so as to adequately provide housing and basic civic amenities. Rajiv Awas Yojna (RAY) - another flagship programme launched in 2011has multiple objectives, viz. providing affordable housing to the urban poor, give them decent living condition, make the cities slum free, enabling reforms to address some of the causes leading to creation of slums among other. This mission is 
supposed to cover nearly 250 cities, having population of more than one lakh across the country by the end of 12th Plan (2017). It's expected to progress at the pace set by the states and allows urban poor to buy or rent and buy. However, affordability still remains the major concern. Deepak Parekh Committee (2004), which presented a report on Affordable Housing to the Ministry for Housing and Urban Poverty Alleviation, quantified affordability in terms of money which as per the recent price index should be around Rs. 3000. However, Kundu(2013) raises his apprehension, thus says:

"Doing a backward calculation, it is evident that these households simply cannot pay this monthly installment. If you look at the consumption expenditure data for the bottom $30 \%$ of the population in 2009-10, the maximum monthly payment that could be paid (that is almost total nonfood expenditure) would Rs. 800 at prices prevailing at that time. At current prices, the figure can be revised to around Rs. 1000. It was clear that requiring Rs. 2800 as monthly payment would imply exclusion of the neediest." (Kundu 2013: 11)

Though some studies including those based on Census 2011 (shown in Table 1) also reveal that there has been considerable increase in the Housing Stock from 18.7 crore in 2001 to 24.5 crore in 2011, indicating a growth of 30.7 percent (Report on Trend and Progress of Housing In India, 2012). However, eventually, it's not about supply of housing rather affordable housing which remains a big challenge for India's urbanization.

Table 1. Increment in Housing Stock

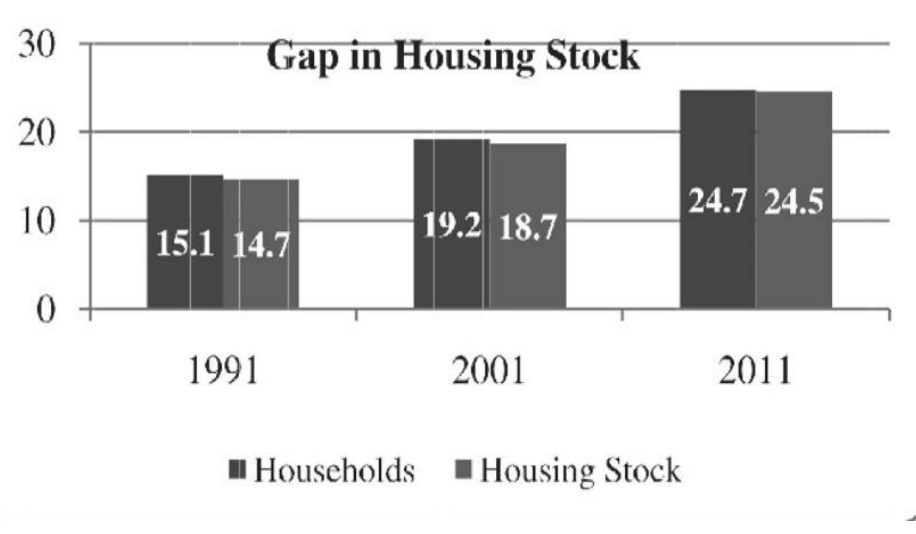

\begin{tabular}{|c|c|c|}
$\begin{array}{c}\text { Census } \\
\text { Year }\end{array}$ & $\begin{array}{c}\text { Households } \\
\text { (in crore) }\end{array}$ & $\begin{array}{c}\text { Housing } \\
\text { Stock } \\
\text { (in crore) }\end{array}$ \\
\hline 1991 & 15.1 & 14.7 \\
\hline 2001 & 19.2 & 18.7 \\
\hline 2011 & 24.7 & 24.5
\end{tabular}

Source:Report on Trend and Progress of Housing In India, 2012, National Housing Bank. http://nhb.org.in/Publications/Report-Trend-and-Progress-of-Housing-in-India-2012.pdf 
However, despite various efforts the demand and supply gap between affordable housing and buyer remains. It's also due to the large-scale urban migration, scarcity of land, rising construction cost and unchecked profiteering. This syndrome affects those at the bottom of the pyramid the Economically Weaker Sections (EWS) and Lower Income Group (LIG) more severely as compared to the Middle and the Higher income groups as it's evident from Table 2.

Table 2. Housing Shortage in Urban India

\begin{tabular}{|c|c|c|c|c|}
\hline & $\begin{array}{c}\text { Monthly } \\
\text { Per Capita } \\
\text { Expenditure }\end{array}$ & $\begin{array}{c}\text { Estimated } \\
\text { Number of } \\
\text { Households } \\
(2007)^{*}\end{array}$ & $\begin{array}{l}\text { Housing } \\
\text { Shortage } \\
\text { in million } \\
(2007)\end{array}$ & $\begin{array}{c}\text { Percentage } \\
\text { Shortage }\end{array}$ \\
\hline EWS & $0-3,300$ & 21.81 & 21.78 & $99.9 \%$ \\
\hline LIG & $3,301-7,300$ & 27.57 & 2.89 & $10.5 \%$ \\
\hline MIG & $7,301-14,500$ & \multirow{2}{*}{16.92} & \multirow{2}{*}{0.04} & \multirow{2}{*}{$0.2 \%$} \\
\hline HIG & 14,501 and above & & & \\
\hline \multicolumn{2}{|c|}{ Total Shortage } & 66.30 & 24.71 & $37.3 \%$ \\
\hline
\end{tabular}

Source: Report of the Technical Group (11th Five Year Plan: 2007-12) on Estimation Of Urban Housing Shortage.http://mhfcindia.com/Affordable\%20Housing\%2olndia-1.pdf

\section{Water and Sanitation}

Water and sanitation are concurrent issues and influence each other in more ways than one. Nevertheless, they're marked with huge deficit both in terms of supply and management. Consequently, they pose one of the major challenges urban and peri-urban areas of India are faced with. Large-scale migration to cities is converting the erstwhile villages into disorganized urban sprawls which often remain outside the purview of urban planning or administration for a long time. Ghosh and Sugam (2013) in their report on Urban Water and Sanitation in India underscore that: "Water supply and sanitation utilities in India have suffered from poor design, poor operation and maintenance practices, lack of accountability, poor data and transparency, and inadequate investments."

Water and sanitation are India's two most pressing developmental challenges. Providing safe and reasonably priced drinking water and sanitation services to the ever-growing urban population remains a daunting task for the bodies of urban governance. It's basically the urban poor who bears the burden of unhygienic, inadequate water supply and poor sanitation services. Another impact is to be found on the depletion of groundwater table due to 
unregulated and unsustainable groundwater pumping. Poor maintenance of the supply line results in huge amount of leakage and loss of water. The dependence on water tankers (often run by water mafia) is a result of government's failure in supplying adequate potable water to the people.

According to the Ministry of Urban Development report (2011) on Household Amenities with respect to Drinking Water Sources and Latrine Facilities in Urban India so far only 72\% urban population has water available in its premises while just 32\% population receives treated potable water. The status of sanitation is even worse. $18.6 \%$ urban household has no access to any sort of sanitation facilities in their houses. Open defecation is a common sight both in the rural and urban areas. The National Urban sanitation Policy (NUSP), 2010 of the Government of India highlights the demand and deficit gap in the area of urban sanitation. According to the report, 12.04 million (7.87\%) Urban households do not have access to latrines and therefore people defecate in the open. On the other hand only 5.48 million (8.13\%) Urban households have access to community latrines while 13.4 million households (19.49\%) use shared latrines. Besides, 12.47 million (18.5\%) households do not have drainage network and 26.83 million (39.8\%) households are connected to open drains. This makes the situation scary. Figure 3 and 4 presents a glimpse of the status of water and sanitation facility in urban India.

Figure 3. Sources of Drinking Water in India

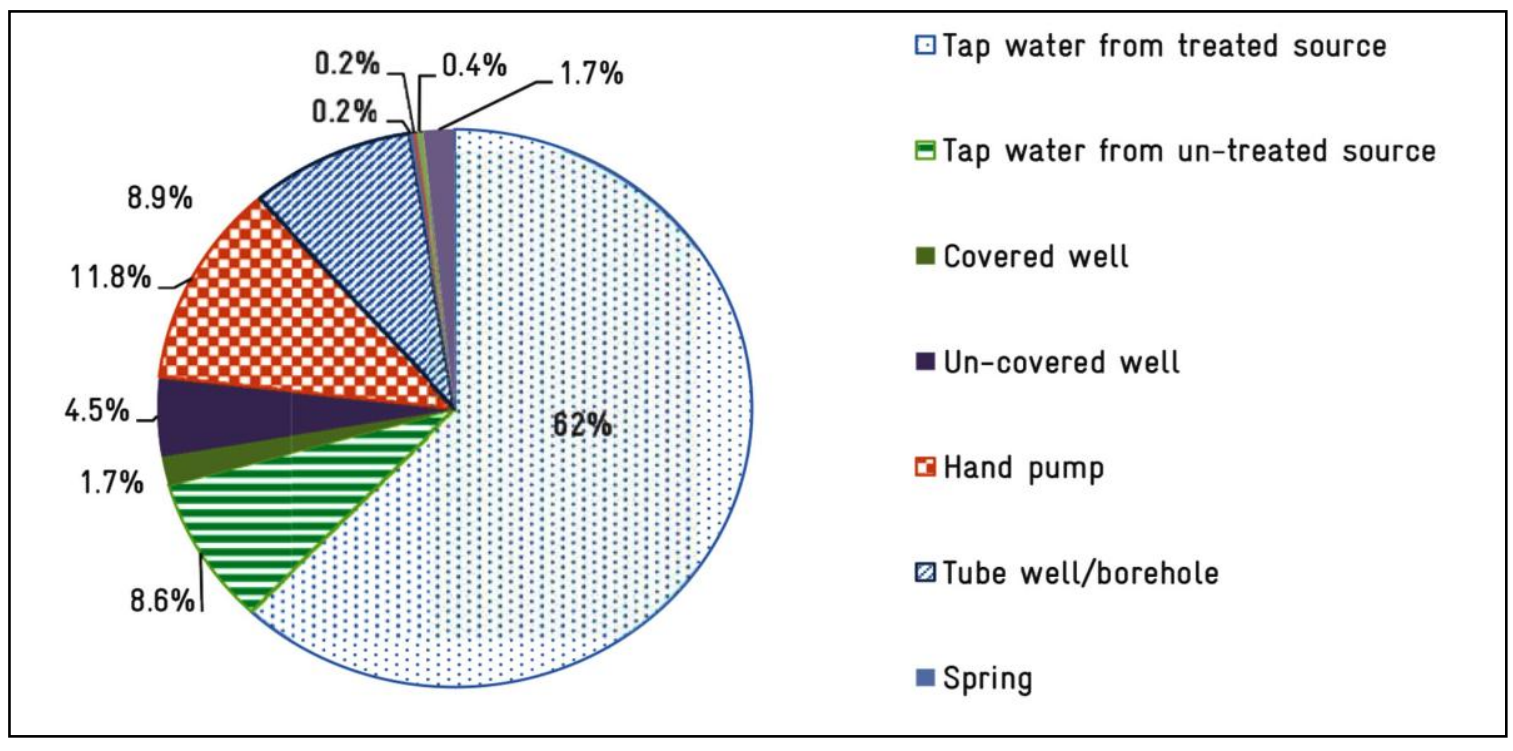

Source: Council on Energy, Water \& Environment, 2013 http://ceew.in/pdf/CEEW-Veolia-Urban-Water-and-Sanitation-in-India-Nov13.pdf 
Figure 4. Toilet Facility in Urban Household in India

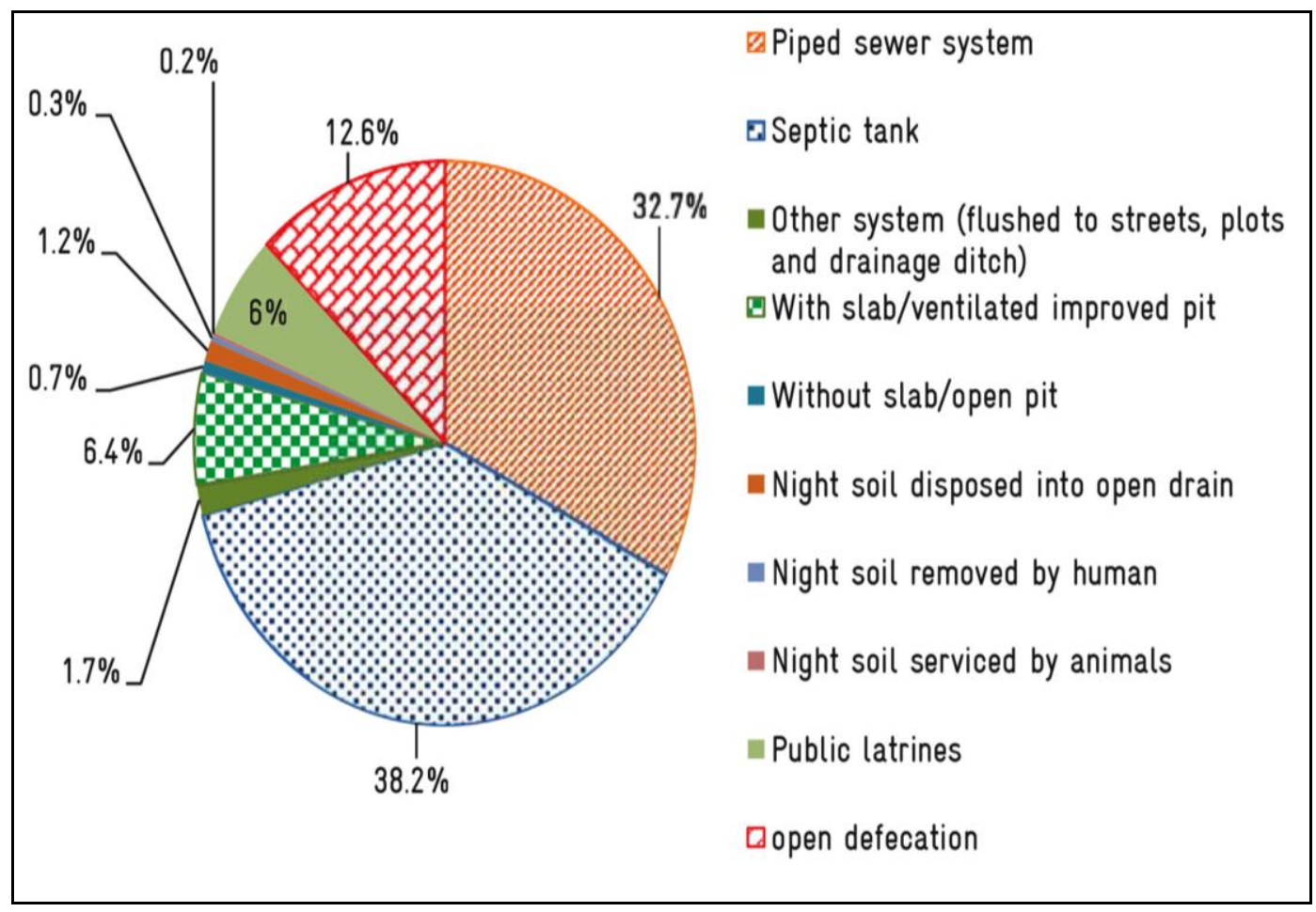

Source: Council on Energy, Water \& Environment, 2013

http://ceew.in/pdf/CEEW-Veolia-Urban-Water-and-Sanitation-in-India-Nov13.pdf

NUSP seeks to transform Urban India into community-driven, totally sanitized, healthy and livable cities and towns. However, sanitation in India remains a challenge because is not only a matter of government intervention but also ensuring people's participation. It's not a onetime achievement rather an ongoing process involving discernable change in behavior, system and practices. Meeting international standards and obligations in a time bound manner is yet another challenge. Being a signatory nation of the Millennium Development Goals (MDGs), it's expected to: "extend access to improved sanitation to at least half the urban population by 2015, and 100\% access by 2025."(NUSP 2010).This means extending sanitation coverage to households without improved sanitation, and providing adequate sanitation facilities in public places so as to make cities open- defecation free. The NUSP vision entails that:

"All Indian cities and towns become totally sanitized, healthy and livable and ensure and sustain good public health and environmental outcomes for all their citizens with a special focus on hygienic and affordable sanitation facilities for the urban poor and women." (NUSP 2010: 7) 
Swachh Bharat Mission (Clean India Mission) initiated by the Narendra Modi government is also meant to give a new fillip to the NUSP. It aims to achieve the following:

1. Elimination of open defecation

2. Eradication of Manual Scavenging

3. Modern and Scientific Municipal Solid Waste Management

4. To effect behavioral change regarding healthy sanitation practices

5. Generate awareness about sanitation and its linkage with public health

6. Capacity Augmentation for ULB's

7. To create an enabling environment for private sector participation in Capex (capital expenditure) and Opex (operation and maintenance)

The estimated cost of implementing SBM (Urban) is Rs. 62,009 Crore. Out of this the Government of India share will be Rs. 14,623 Crore. It will be augmented by an additional amount equivalent to $25 \%$ of Gol funding, which is Rs. 4,874 Crore, contributed by the States as State/ULB share. The challenge before the mission is to:

1. Build household toilets and convert insanitary latrines into pour-flush latrines

2. Community toilets

3. Public toilets

4. Ensure solid waste management

5. Create IEC \& Public Awareness

6. Help capacity building and administrative and office expenses (A\&OE)

One of the biggest challenges of sanitation in India is also concerned with changing people's behavior towards healthy sanitation practices. While maintaining personal hygiene is often a priority, maintaining social hygiene is a rare practice. No amount of investment will ensure good sanitation unless it becomes people's commitment and social culture.

The development discourse in India still revolves around the basic issues called Bijli, Sadak, Pani (electricity, road and water). They're part of the larger discourse of development common to both cities and villages and remain relevant because they constitute major part of India's development deficit even as India embarks upon the seventh decade of its independence. Affordable housing, water and sanitation, road, electricity are the challenges Indian cities (and villages too) are faced with. One of the reasons is that at the policymaking level India has been somewhat hesitant in accepting the importance of urban development 
for a long time. The syndrome of urban underdevelopment is a reflection of that reluctance too.

\section{Urban Development Deficit and the Challenges}

Being an agrarian society India lives in villages. As such, it was just natural that rural development enjoyed a position of relative pre-eminence in the social policies and programmes. Both centre and states earmark larger chunk of budgetary allocation for various schemes of rural development from giving subsidy to electricity, fertilizer, building canals, roads etc. Although despite the allocation and programmes both village and its prime occupation agriculture remained impoverished leading to urban migration and farmers' suicide. This is not a suggestion for any curtailment in allocation on rural development rather an argument to improve governance and service delivery. Rural bias which suited the apparent pro-poor agenda of different governments and political parties, in course of time became the reason of obvious antipathy towards urban development. Tiwari et al. (2015) have also observed that:

\footnotetext{
"It will not be presumptuous to assume that: "the physical an social outcomes in the urban India over the last six decades, and the debate around "urbanization" give the impression that in India urbanization was "reluctant." (Tiwari et al. 2015: 21)
}

The industrial, energy, social development policies seemed to be more inclined towards rural India often at the cost of the due attention that cities deserved. On the other hand, despite the policy tilt towards villages, cities continued to grow in size and number providing better opportunities of livelihood, education, safety and growth to individuals. The Geographical Area of India is 3,287,590 sq. km. Out of this 3 percent of the total area, which is 98617.2 sq. $\mathrm{km}$, is urban. Not only this $2 / 3$ of India's GDP and $90 \%$ of government revenue are generated by even less than $1 / 3$ of India's urban population living in big and megacities. Despite that India's urban spending is markedly low in comparison to China and UK. India's per capita spending including capital and operational expenditure is $\$ 50$ vis a vis China's - \$362 and UK - \$1772. According to McKinsey Global (2010) Report, India requires an investment of $\$ 1.2$ trillion by 2030 in urban infrastructure which is equivalent to per capita average annual spending of appx. \$250. Ministry of Urban Development's estimated expenditure on urban infrastructure till 2031 is given in the figure 4.1. 
Figure 4.1. Estimated Expenditure on Urban Infrastructure Till 2031

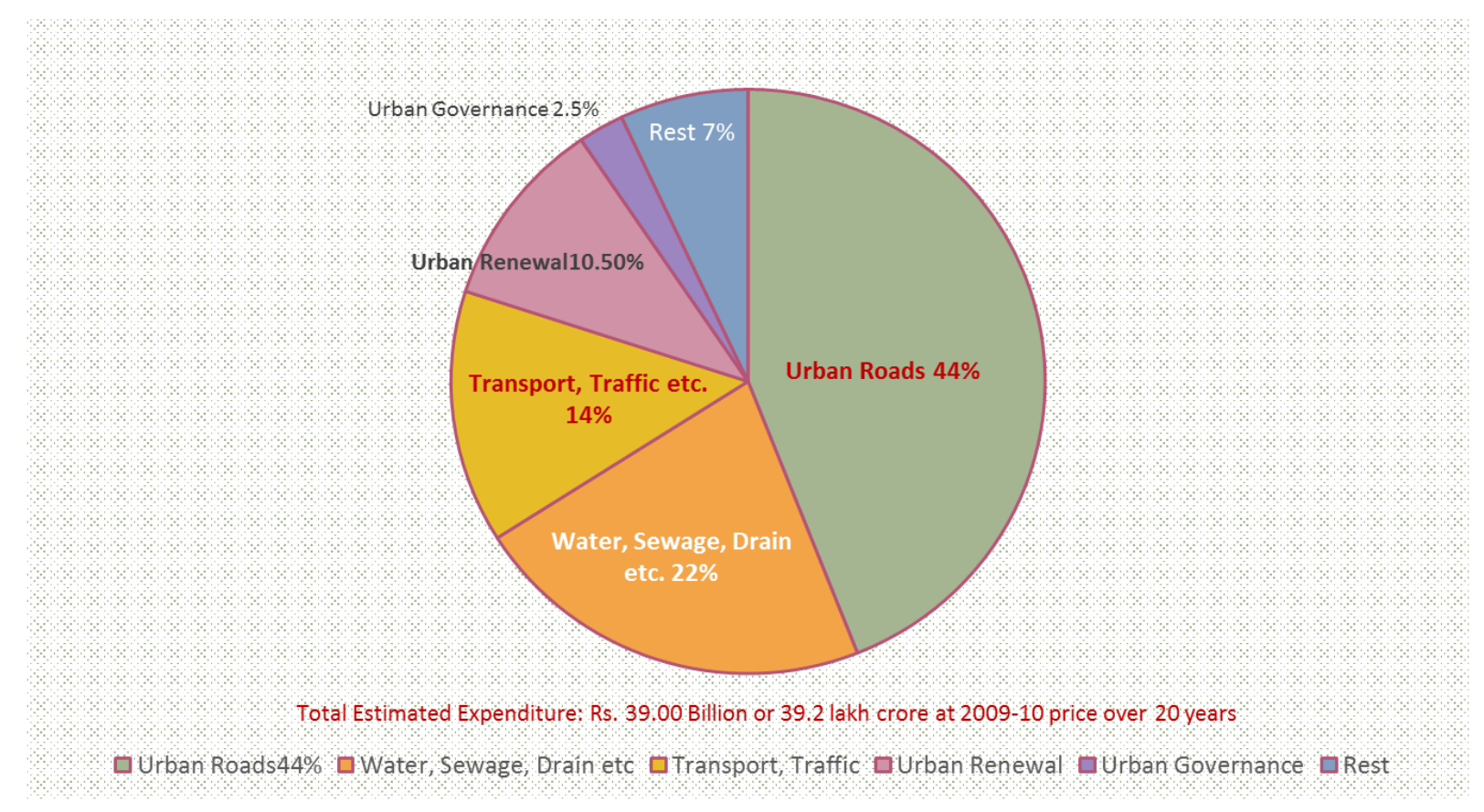

Source: MOUD http://moud.gov.in/urban_infrastructure

The development of cities has also become a victim of the 'rural-urban divide' debate. In the post liberalization and globalization era when cities are acquiring the status of the growth engine of economy, they require a more fair treatment than being neglected. 31 percent population of India living in 3 percent of its total land area has its own complications and challenges in terms of infrastructure, quality of life, safety and sustainability. Figure 5 presents a glimpse of the challenges. 
Figure 5. India's Urban Challenges at a Glimpse

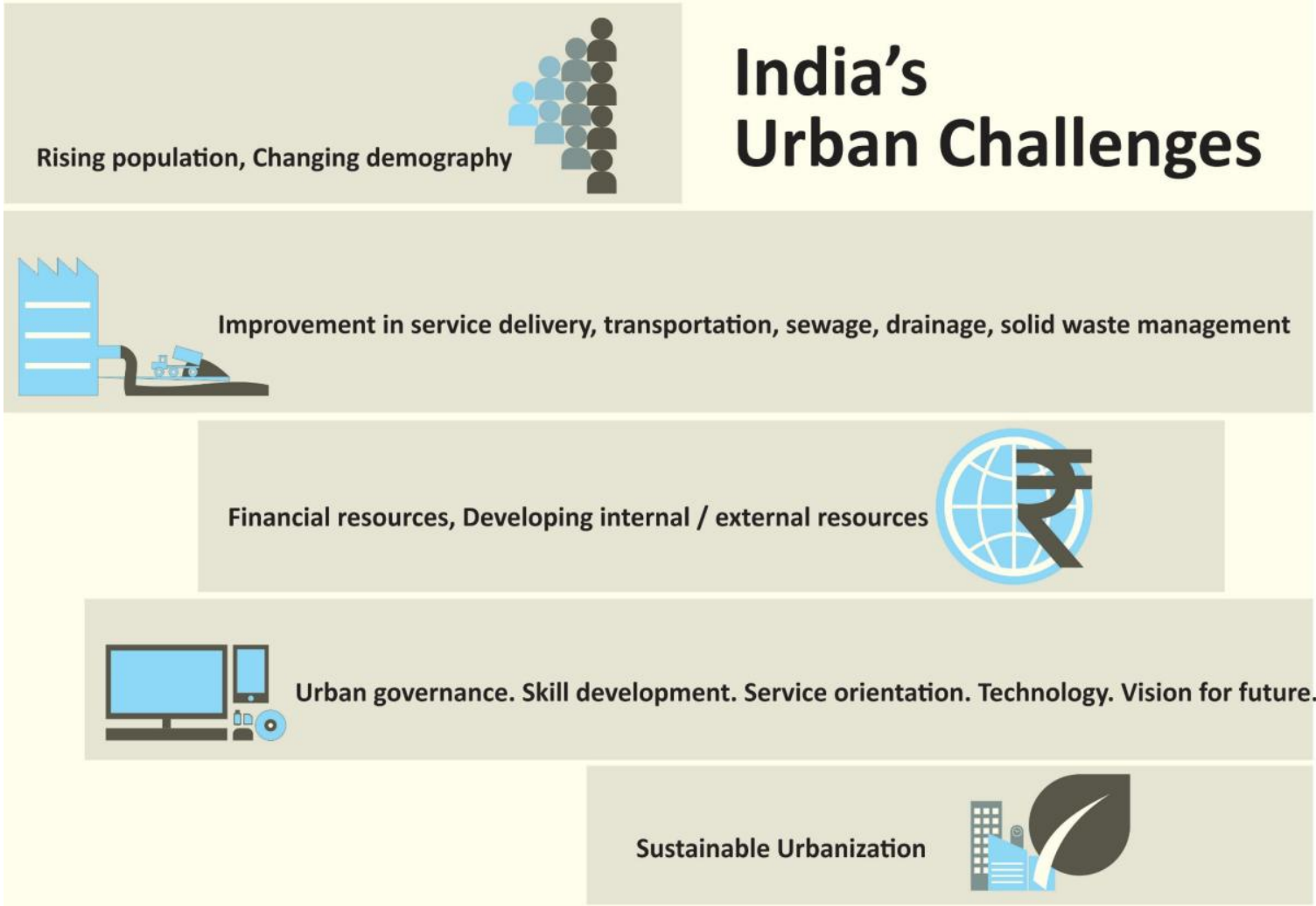

Widely held view that urbanization in India is slower as compared to other nations is not true anymore. World Bank turns that theory on its head. It finds suburban growth as the signature of India's urbanization. Rural areas adjoining major metropolitan cities are witnessing faster economic growth, generating higher employment than the mega-cities. 'Urbanization beyond Municipal Boundaries' examines the phenomenon of India's rapid suburbanization, looking at its impact on efficiency, inclusion and sustainability. Onno Ruhl, World Bank's country director for India believes that with the right policies in place, the faster a country like India urbanizes, the faster it could reduce poverty and increase shared prosperity. Experience the world over has shown a crucial link between urbanization and economic growth. Urban policymakers in India are not oblivious to these realities anymore. But the deficit of previous planning will take some more time to cover up the loss. 


\section{Smart City for Urban Revival}

Rising urbanization and global integration of cities in terms of employment, business, finance, production and services among other required a new perspective to look at the nature and function of the cities of the $21^{\text {st }}$ century and beyond. India can't be an exception to this. Globalization has brought the world closer and the integration requires more efficient system. Al Gore, the former American Vice-President in 1998 gave the concept of "digitalized world" and later in 1999 "digitalized city" which through the IT intervention was envisioned as a process to create and manage the cities of the future. Technology experts looked at "smart cities" as further extension of digitalized cities itself. Harrison and Donnelly (2011) observe that: "The phrase Smart Cities is not new. It may have its origins in the Smart Growth [Bollier, 1998] movement of the late 1990s, which advocated new policies for urban planning."Use of the word 'smart' as a prefix to 'city' raises natural curiosity. However, in a simpler sense the prefix 'smart' is a euphemism for intelligent, apt and efficient application of technology and design for running the civic system.

\section{The Technological Perspective}

While keeping technology at the centre of innovation, international IT and Technology majors like Hitachi, IBM, Cisco, Siemens have defined it with difference in emphasis. For Hitachi, its vision of smart city means a city that: "seeks to satisfy the desires and values of its residents, with the use of advanced IT to improve energy efficiency and concern for the global environment as pre-requisites, and in so doing maintains a "well-balanced relationship between people and the Earth." The emphasis is on building harmonious relationship between man and environment by leveraging technology and bring them together in such a manner that the concern of environmental sustainability is taken care of. IBM recognizes the finite nature of resources and envisions smart city as one that: "uses technology to transform its core systems and optimize the return from largely finite resources. By using resources in a smarter way, it will also boost innovation, a key factor underpinning competitiveness and economic growth." (IBM: 2009). Sustainable economic development is what Siemens believes is at the core of smart city as it explains: "A city can be defined as 'smart' when social capital, traditional (transport) and modern (ICT) communication infrastructure fuel sustainable economic development and a high quality of life." (Siemens: 2014). Interestingly, all the different stakeholders have different perspectives on smart cities based on their own points of view. The engineers and technologists for example may look at it as a complex system having number of layers. Architects may look at it from spatial and planning perspective. For 
social researchers it's a place for living, social inclusion and enjoying community life. Government and civic authorities may like to view it: "in terms of economic growth and new or improved city services supported by policy initiatives designed to effect change." (Falconer and Mitchell: 2012). However, a working definition of smart cities by the British Standards Institution brings better clarity. According to BSI (2014): 'Smart cities' is a term denoting the effective integration of physical, digital and human systems in the built environment to deliver a sustainable, prosperous and inclusive future for its citizens.'

\section{India's Foray into Smart Cities}

India's urbanization projection reveals that by 2031 the urban population in India will touch 600 million. Thus, next generation cities will be obliged to satisfy users' needs and ensure convenience and growth, while being sensitive to issues of global ecological and environmental concerns at the same time. In its twelfth plan period, the erstwhile Planning Commission of India envisioned smart cities as the engines of growth competing for national and international investment, even as infrastructure development for inclusive and sustainable urban development remained its priority. However, it's under the present government of Narendra Modi that the vision has been converted into a programme with a clear mandate, budgetary allocation, identification of cities and action plans. Smart city program was launched in the year 2014 in a mission mode. According to Ministry of Urban Development objective of the smart city mission is to:

"promote cities that provide core infrastructure and give a decent quality of life to its citizens, a clean and sustainable environment and application of 'Smart' Solutions. The focus is on sustainable and inclusive development and the idea is to look at compact areas, create a replicable model which will act like a light house to other aspiring cities. You can find detailed information about the Smart Cities Mission, Smart city features, selection process, implementation, financing, etc. (Smart City Portal by Ministry of Urban Development: 2015)

Smart technologies, including information and communication technology (ICT), will not only become the backbone of urban infrastructure, but also expected to add value to civic services and ensure smooth service delivery. The government plans to create smart cities as satellite towns around larger cities and by modernising the current mid-sized cities. It means, they will be developed not on acres of vacant land but in 'statutory' towns owned by municipalities and corporations and 'census' towns in the rural and peri-urban areas. Many such areas, 
however, may have their own socio-economic-administrative limitations. If India is looking at smart cities as a response to its changing demography and consequent urbanization, it's required to put together the perspective of multiple stakeholders; technologists, urban planners, designers and city dwellers, alongside policy makers.

\section{Smart City Challenges for India}

There's no doubt that growing interest in smart cities has led to lots of social, theoretical and technological discussions. However, implementation and initiatives have been far less in comparison to the hype. The problem lies with the numerous hindrances on way to the adoption of Smart City solutions. For example: people's interface with newer technologies is unverified; new technology will alter the existing system of running the cities; in a socioculturally diverse society like India people's familiarity with technology is not at the same level. Another set of challenge include the communication gap between the city managers, policy planners and technologists with each of them pursuing their own mandate. Technologists also need to understand how cities are operated, financed, regulated, and planned. Smart Cities, however, present an opportunity to integrate physical city infrastructures-from utilities, transportation, and real estate to city services. IBM for example proposes to make a smart city which is interconnected, instrumented and intelligent. The foremost challenge lies in measuring and increasing urban capacity for smartness (Anthopoulas, 2015). The allocation of the government of India on smart city initiative was Rs 7,060 crore (70.6 billion) in the 2014-15. However, the requirement will be much more and making the project financially viable is a big challenge. Smart cities will not function unless the people themselves are smart enough to appreciate the very purpose of it and then interact with the new systems. Chourabi et al. (2012) have identified eight critical factors which are essential for smart city initiative namely: management and organization, technology, governance, policy context, people and communities, economy, built infrastructure and natural environment. These will be some of the major challenges for the Indian smart city initiative as well. A holistic understanding of the existing urban system will be a must followed by the expertise of integrating technology, community, environment and socio-economic sustainability.

\section{Technology Deficit}

As far as India is concerned, there is an apparent deficit of technology and design intervention in running its civic system which for a large part still depends on manual interventions in different areas viz. solid waste management, traffic control, water supply, urban safety and so 
on. Dirks and Keeling (2009) have identified six core systems of the cities from the operational point of view which include: people, business, transport, communication, water and energy. These are not isolated systems. There is a synergy between them which promotes optimum performance and efficiency. They call the six core systems, a "system of systems." The interconnection between systems may be visualized as under in figure 6 .

Figure 6

Sample of interrelationships between core city systems.

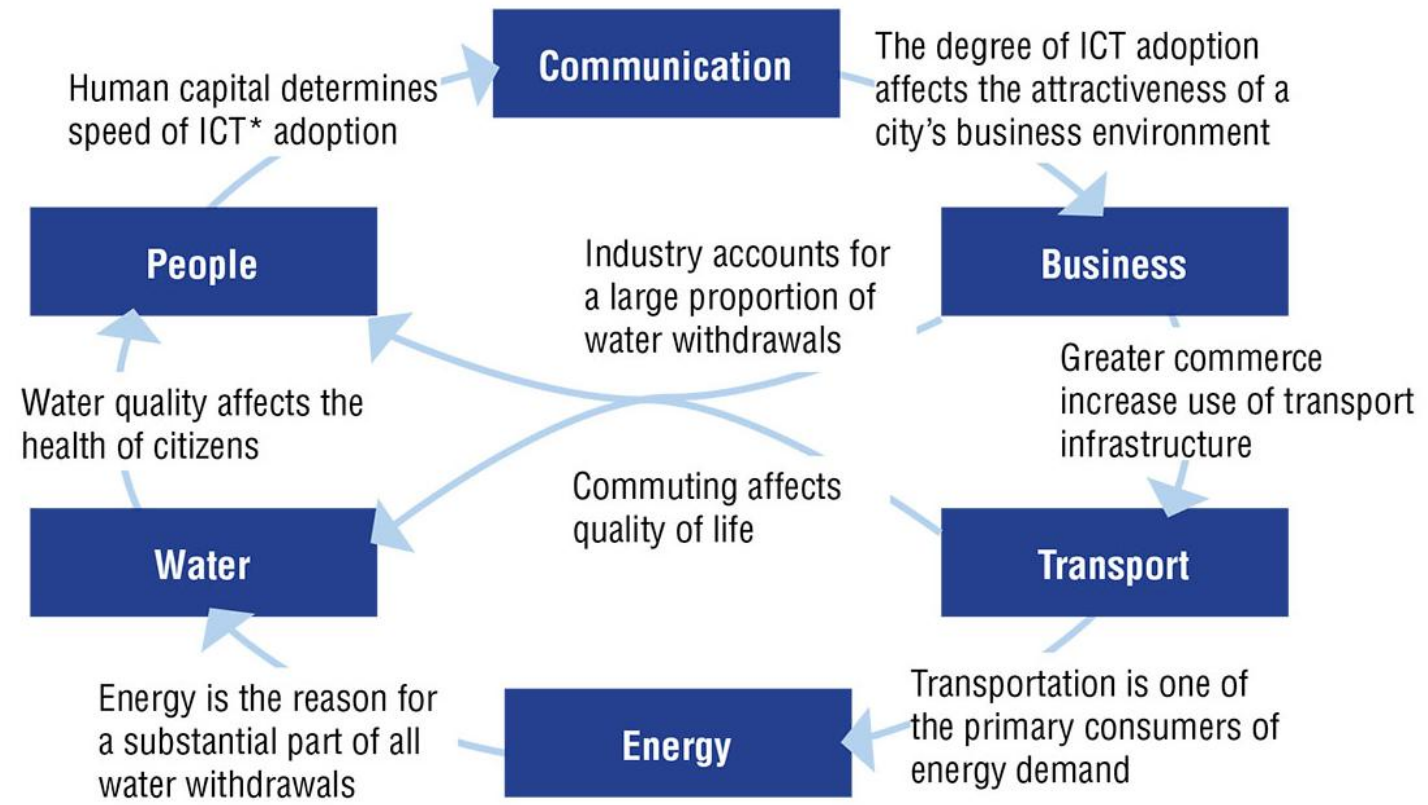

*Note: ICT=Information and communications technology.

Source: IBM Center for Economic Development analysis.

In India smart cities will have to transform these systems to their highest level of efficiency through technological intervention so that the use of limited resources may be optimized. The premise on which the concept of smart cities rests indicates that in the light of the rising challenges of urbanization systems governing the cities need revolution rather than evolution. For example, communication in Indian cities both in terms of transport of people and data need a radical change which is futuristic and sustainable socially, economically and environmentally. Delhi, which is the fifth most populous city in the world having an estimated population of 17.8 million (2014), is also one of world's most polluted cities. The Air Quality Index (AQI) of Delhi remains in the range of 300 which is considered very unhealthy and hazardous. Vehicular pollution is the largest contributor to this mess followed by industrial 
pollution. As per the data of Delhi Government 847 million motor vehicles (of all types) were registered in Delhi till March 2015. As such, the city requires urgent smart interventions to improve the public transport system so that problems like air pollution, congestion, road rage etc. can be reduced to the limit of human tolerance. Water supply, generation, optimum consumption and seamless distribution of power are among some other major challenges facing Indian cities. For example, in most parts of the world including India, half of the water supplied is wasted due to leakage in pipeline. Besides, the issue of contamination also looms large. The problem cannot be tackled unless smart technology is introduced tomake assessment of the entire water ecosystems of a city comprising of rivers and reservoirs to pipeline and give the users timely information about their own water usage and wastage. There're working models as in Galway, Ireland, which uses technology based on advanced sensor network which provides real-time data and its analysis to all stakeholders.

\section{Conclusion}

Cities are meant for people because it's people who build cities. They build it the way they want to live. They have always responded to the challenges of their time and evolved new techniques and systems to run cities. For instance, way back in 3300 BCE when Indus valley people developed the technique of town planning and drainage system they were the best innovations in the urban system. Roman also successfully experimented with similar systems in their cities which included sewers, city systems, roads and highways etc. The irrigation system of the $14^{\text {th }}$ century Vijaynagar Empire in southern India in the form of tank systems and simple diversion structures across large rivers like Tungabhadra were another example of smart innovation in water management. It was based on the existing understanding of Hydraulics and Hydrology of the contemporary engineers known as Jalatantrisor the specialists of water management.

Critics of the idea of smart city believe that cities have always been smart and their intelligence resides in the people (Greenfield, 2013). The semantics of smart cities however explain different approaches of looking at them from different perspectives viz. resilience, business, growth of citizens or services within an urban environment among other. The optimism of 'the smart city' is a kind of rhetorical move within a much larger space of potential (Greenfield 2013). Most of our present urban problems have been created by technology itself by enabling large scale production, consumption, aspirational lifestyle, concentration of economic activities at certain places and so on. Now technology itself is trying to innovate smart processes to clear the mess. But unless technological innovations are aligned with social innovations India's urban chaos will not improve much. Social innovation 
means implementation of new ideas including technology, design, products, services and models in order to meet social needs. It must go alongside the technological innovation, which has overpowered the idea of smart cities. Social innovation will help in the identification of emerging or inadequately met social needs of the cities, development of new solutions and analyzing the efficacy of the new solutions. A successful model of smart city in India will be one which will use technology (including ICT) to empower people to innovate new ideas to achieve urban sustainability.

\section{References}

Ahluwalia, I. J., R. Kanburand P. K. Mohanty" Challenges of Urbanisation in India."Urbanisation in India.Eds.Ahluwalia, I.J., R. Kanbur, and P. K. Mohanty. New Delhi, Sage India, 2014.

Ahluwalia, I. J. and P. K. Mohanty. "Planning and Market for Urban Development in India." Urbanisation in India. Eds. Ahluwalia, I.J., R. Kanbur, and P. K. Mohanty. New Delhi, Sage India, 2014.

Anthopoulos, Leonidas G. “Understanding Smart City Domain.” Transforming City Government for Successful Smart Cities. (Ed) Bolivar, M P R. London, Springer, 2015.

Bolivar- M P R (ed). Transforming City Governments for Successful Smart Cities. Switzerland, Springer International Publishing, 2015.<https://books.google.co.in/books?id=m6kYCgAAQBAJ\&pg=PA20\&dq=smart+city++ Hitachi\&hl=en\&sa=X\&ved=oCCoQ6AEwAWoVChMI7bnUylCyxwIVogiOCh1X2gNf\#v=onepage $\& q=$ smart $\% 20$ city $\% 20-\% 20$ Hitachi\&f=false $>$

Bollier, D., How Smart Growth Can Stop Sprawl, Washington, DC.Essential Books, 1998.

BSI:180, Smart cities - Vocabulary, D.f.B.I. Skills, Editor. 2014, BSI Group Haedquarters: London.

Chandramouli, C. Rural urban distribution of population.<http://censusindia.gov.in/2011-prov results/paper2/data_files/india/Rural_Urban_2011.pdf $>$

Chourabi., H., Nam., et al. Understanding Smart Cities: An Integrative Framework. $14^{\text {th }}$ Hawaii International Conference on Systems Science, Hawaii. 2012

CPHEEO, Ministry of Urban Development, "An Analysis of 2011 Census Data on Household Amenities with respect to Drinking Water Sources and Latrine Facilities in Urban Areas of the Country", http://urbanindia.nic.in/programme/uwss/ AnalysisHouseholdAmenities.pdf

Dirks, Susanne and Mary Keeling. "A vision of smarter cities: How cities can lead the way into 
a prosperous and sustainable future.” IBM Global Services, New York, 2009.

Greengfield, A., This is Part I of The city is here for you to use: 'Against the smart city'. New York Do. 2013.

This is Part I of The city is here for you to use: 'Against the smart city'. New York

Do. 2013.

"Growth of smart cities will be decided by citizens, not govt: Modi". New Delhi, Hindustan Times, June 25, 2015. http://www.hindustantimes.com/india/growth-of-smart-cities-will-bedecided-by-citizens-not-govt-modi/story-wtcooOLfkgeunwgKDBOM2J.html

Guidelines for Swachh Bharat Mission (SBM) 2014.Govt. of India, Ministry of Urban Development.http://moud.gov.in/sites/upload_files/moud/files/SBM_Guideline.pdf

Harrison, Colin. \& Ian A. Donnelly.A Theory of Smart

Cities.http://journals.isss.org/index.php/proceedings55th/article/viewFile/1703/572;

KPMG. Indian Real Estate-opening doors. 2014.

<https://www.kpmg.com/IN/en/IssuesAndInsights/ArticlesPublications/Documents/Indianreal-estate-Opening-doors.pdf>

India's urban awakening: Building inclusive cities, sustaining economic growth. McKinsey Global Institute, 2010

National Urban Housing and Habitat Policy 2007. Govt. of India, Ministry of Housing \& Urban Poverty Alleviation, New Delhi.http://mhupa.gov.in/policies/duepa/HousingPolicy2007.pdf

Govt. of India, Ministry of Housing \& Urban Poverty Alleviation, New

Delhi.http://mhupa.gov.in/policies/duepa/HousingPolicy2007.pdf

Govt. of India, Ministry of Housing \& Urban Poverty Alleviation, New

Delhi.http://mhupa.gov.in/policies/duepa/HousingPolicy2007.pdf

Kundu, Amitabh. "Dream of Making India SlumFree: A Myth or Reality"RajivAwasYojana (Ray) And Slum-Free CitiesProceedings of a seminar organised on $13^{\text {th }}$ August 2013. Actionaid. http://www.ciric.in/wp-content/uploads/2015/02/RAY-REPORT-FINAL-Revised-Layout.pdf

Paul, Samuel. "Generating Demand for Good Governance."Urbanisation in India. Ed.

Ahluwalia, I.J., Kanbur, R. and Mohanty, P.K.New Delhi, Sage India, 2014.

Report on Trend and Progress of Housing In India, 2012. http://nhb.org.in/Publications/ReportTrend-and-Progress-of-Housing-in-India-2012.pdf 
Sankhe, Shirish, et. al. India's Urban Awakening: Building inclusive cities, sustaining economic growth. 2010, McKinsey Global Institute.file:///C:/Users/user/Downloads/MGI_Indias_urban_awakening_full_report\%20(1).pdf World Urbanization Prospect 2014, Revision.http://esa.un.org/unpd/wup/Highlights/WUP2014Highlights.pdf

Sengupta, Urmi. "New frontiers and challenges foraffordable housing provision in India." Affordable Housing in the Urban Global South.Ed. Bredenoord, Jan., Lindert, P.V. and Smets, Peer. New York, Routledge, 2014.

Sugam, R. and ArunabhaGhosh. Urban Water and Sanitation in India: Multi-stakeholders Dialogue for Systemic Solutions. Delhi, Council on Energy, Water \& Environment, 2013. http://ceew.in/pdf/CEEW-Veolia-Urban-Water-and-Sanitation-in-India-Nov13.pdf

Tiwary, Piyush.,Ranesh Nair., PavanAnkinapalli., JyotiRao., PritikaHingorani., ManishaGulati.(Eds.) India's Reluctant Urbanization. UK, Palgarve Macmillan, 2015. https://books.google.co.in/books?id=hooMCgAAQBAJ\&pg=PA49\&lpg=PA49\&dq=india+urban +infrastructure+challenges+-+Mckinsey+pdf\&source=bl\&ots=OHRXiFh94j\&sig=IuBpQ81ATDTdx1bfWYECYjTI3w\&hl=en\&sa=X\&ved=oCD4Q6AEwB2oVChMlo_ogJehyAIVzhOCho28gCL\#v=onepage \&q=india\%20urban\%20infrastructure\%20challenges\%20\%20Mckinsey\%2opdf\&f=false 